The Government tightened its control in a way that was possible only because June is a quiet period. Moreover, had the ban continued the public would have probably become used to the procedure for obtaining benefit without a doctor's certificate. Patterns of group behaviour usually take time to react to altered circumstances, and this has been shown in industrial populations adapting to changes in sick-pay schemes. ${ }^{2} 3$ Three weeks is too short to allow such changes to emerge. Any estimate of the possible savings in sickness and injury benefit last June should also take into account the likelihood that most, if not all, of the "missing" spells would have been brief and that extra administrative costs were also incurred. Finally, most of the industrial organizations represented at the Production Engineering Research Association's conference on absenteeism in September had found no appreciable reduction in absence rates during the period of the ban.

The problems of sickness absence and its certification are not unique to Britain. Rising rates of absence have been reported by many industrialized countries. ${ }^{3}$ Many doctors resent this duty as a waste of time which could be better spent, and see the introduction of self-certification as one way to reduce workload in general practice. ${ }^{5}$ In 1969 the Representative Body asked the Council of the B.M.A. to review the whole question of certification with a view to its removal from the general practitioner's terms of service. ${ }^{6}$ Laymen do not always realize that sickness absence is not necessarily a consequence of sickness but also of a reluctance to work. This is particularly true of those shorter episodes of absence which are now so frequent and troublesome. The recognition that it is often the patient rather than the doctor who effectively decides whether or not he is fit for work has led to a demand for self-certification. However, large sums of public money are involved ( $₫ 382 \mathrm{~m}$. paid in benefit in Britain in 1969), and to judge by the Swedish experience self-certification for the first week could well result in many more claims. Though the Confederation of British Industry has observed that the effort of going to a doctor is a useful disincentive to unjustified sickness absence, ${ }^{7}$ it is doubtful whether this could be supported by cost-benefit analysis, and is certainly not an argument which would appeal to busy family doctors.

Nevertheless, certain changes might improve the situation. Under present certification regulations a man can claim benefit for only three days out of the first week in the first episode of illness, but if he is off for a fortnight he is entitled to claim 12 days sick benefit. This tends to encourage longer episodes of sickness. Furthermore for a second episode of illness in any 13-week period the patient may claim benefit for the full time he is off work. This too may encourage a small minority to have repeated spells on sick pay. Employees covered by com-

1 Annual Report of the Department of Health and Social Security for the Year 1969, London, H.M.S.O., 1970.

2 Denerley, R. A., British fournal of Industrial Medicine, 1952, 9, 275

3 Ager, J. E., in Proceedings of the Symposium on Absence from Work attributed to Sickness, ed. A. Ward Gardner, Society of Occupational Medicine, London, 1968

- Taylor, P. J., British Medical Journal, 1969, 4, 705

- Carne, S. J., British Medical fournal, 1969, 1, 147.

- British Medical fournal Supplement, 1969, 3, 67

Confederation of British Industry, Absenteeism, and Analysis of the Problem, London, 1970.

- Taylor, P. J., British Medical fournal, 1969, 1, 144.

Ministry of Labour, Sick Pay Schemes, Report of the National Joint Advisory Council, London, H.M.S.O., 1964.

10 Ministry of Social Security, Explanatory Memorandum to the Family Allowances and National Insurance (No. 2) Bill, 1968, B.110, Family H.M.S.O.

11 Rutter, E. G., and Ottaway, K., Sick Pay, The Industrial Society, London, 1967

12 Department of Health and Social Security, Proposals for Earnings Related Short-Term and Invalidity Benefits. Cmnd. 4124, London, H.M.S.O., 1969. pany sick-pay schemes giving normal wages, less national insurance benefit, from the first day have less incentive. The industrial self-certification scheme described in this journal last year $^{8}$ was shown to reduce total time off work at the expense of more single-day absences. Such an arrangement could not be expected to succeed without a company sickpay scheme, and so long as the existing system of "waiting days" continues self-certification for National Insurance is unlikely to reduce sickness absence. However, self-certification could lessen the family doctor's work load, and for this reason should be studied carefully. The abolition of waiting days and payment of benefit from the first day has been rejected on the ground that the costs would rise to an unacceptable level. ${ }^{9}$ An alternative, to make the waiting days absolute and never paid, would have saved $£ 17 \frac{1}{2} \mathrm{~m}$. in $1968,{ }^{10}$ but this proposal roused strong opposition and was dropped by the Government of the day.

The other difficulty of self-certification is the expansion of controls required. To introduce the Swedish system would probably require some 70 extra full-time doctors, more than 300 sick visitors, and a substantial number of administrative staff to handle the increased number of claims. The system used in Holland, where certification is completely divorced from treatment, would be even more costly for the nation.

Without a change in the existing waiting-day arrangements it would be difficult to reconcile the wishes of doctors to opt out of national insurance certification with the practical and economic difficulties of doing so. If local general practitioners agreed, industrial doctors could issue certificatesa system already in operation in some areas-but there are relatively few such doctors. A more radical change would be to allow state-registered nurses outside hospitals to sign certificates for a limited period of up to, say, a week. Abolition of payment for the first three days of every episode of incapacity would reduce direct costs and remove the incentive for an absence of a fortnight. This might persuade more employers to provide their own sick-pay schemes, few of which have any waiting days at all. ${ }^{11}$ The proposal of the last Government that employers should administer national insurance benefit for periods of up to one month ${ }^{12}$ would be more likely to become acceptable, thereby saving administrative costs, and self-certification could then be reconsidered. Overriding all the administrative aspects, however, is the importance of individual motivation in sickness absence, a difficult problem which calls for more research. Though the. profession can contribute to this, it is not primarily the doctor's responsibility to alter community attitudes. Management must play its full part in what is, after all, a social problem.

\section{Nocturia During Steroid Therapy}

The urinary excretion of water and electrolytes is normally greater by day than by night. This nyctohemeral pattern does not seem to be directly related to the rhythm of corticosteroid secretion, since the phasic electrolyte excretion alters more quickly than the corticosteroid rhythm in response to a change in the sleep-wake cycle. ${ }^{1}$ Furthermore, patients with Addison's disease given small doses of steroids evenly round the clock still show a normal cyclical pattern of electrolyte excretion. ${ }^{23}$ Circulating corticosteroids seem to be necessary, however: the pattern is absent in untreated Addisonian patients, but it 
is not abolished by simple salt restriction. ${ }^{3}{ }^{4}$ It has been known for many years that this rhythm of electrolyte excretion may also be reversed or abolished in diseases such as cardiac and hepatic failure, chronic renal failure, and malnutrition, or during treatment with supraphysiological doses of hydrocortisone or cortisone. ${ }^{4} 5$

Recently J. P. Thomas and his colleagues have reported that $47 \%$ of their asthmatic patients on long-term treatment with modest doses of prednisone admitted to having nocturia. ${ }^{6}$ When prednisone was given as a single dose in the morning this did not stop the nocturia, and preliminary observations suggest that nocturia occurs in steroid-treated patients other than asthmatics. They investigated in detail five patients given prednisone in a dose of $5 \mathrm{mg}$. at $8 \mathrm{a} . \mathrm{m}$. and $9 \mathrm{p.m}$. Urine was collected eight-hourly. The volume of urine passed between midnight and 8 a.m. was significantly greater than that obtained during the daytime collecting periods, and the urine was more dilute. Associated with this increase in flow of dilute urine was a rise in the nocturnal excretion of sodium, potassium, and bicarbonate, and the osmolar clearance was increased. Thus the increase in water excretion was out of proportion to the increased electrolyte excretion. The pattern reverted to normal on stopping prednisone for 48 hours. Serum electrolyte concentrations did not change throughout the 24 hours, and the overall balance of water and electrolytes was not altered.

The mechanism of this phenomenon is uncertain. It seems unlikely that it is related to any sodium-retaining action of the prednisone given during the day, since a potent mineralocorticoid, flurohydrocortisone, given to the prednisonetreated patients at midnight did not influence the increased amounts of urine and electrolytes excreted during the night. Further, the normal pattern of aldosterone excretion was unaltered by the prednisone, being greater by day when the subjects were upright than when they were recumbent at night.

Thomas and his colleagues suggest that the renal effects could be due either to a decrease in proximal tubular reabsorption or an increase in filtered load. In only one of their patients was the inulin clearance greater at night than during the day, and there seems no evidence of a change in filtration rate. J. H. Laragh ${ }^{7}$ and $\mathrm{H}$. E. de Wardener ${ }^{8}$ have recently discussed the evidence supporting the existence of a natriuretic hormone controlling the renal tubular handling of sodium. While the precise nature and site of action of such hormone or hormones is controversial, there can be little doubt that there is more to sodium homeostasis than can be explained by the combined actions of the mineralocorticoids and the reninangiotensin system. It is possible that prednisone might

\footnotetext{
Martel, P. J., Sharp, G. W. G., Slorach, S. A., and Vipond, H. J., fournal of Endocrinology, 1962, 24, 159.

${ }^{2}$ Rosenbaum, J. D., Papper, S., and Ashley, M. M., fournal of Clinical Endocrinology, 1955, 15, 1459

3 Doe, R. P., Vennes, J. A., and Flink, E. B., fournal of Clinical Endocrinology, 1960, 20, 253.

- Rosenbaum, J. D., Ferguson, B. C., Davis, R. K., and Rossmeisl, E. C., fournal of Clinical Investigation, 1952, 31, 507 .

Finkenstaedt, J. T., Dingman, J. F., Jenkins, D., Laidlaw, J. C., and Merrill, J. P., fournal of Clinical Investigation, 1954, 33, 933.

6 Thomas, J.P., Coles, G. A., and El-Shaboury, A. H., Clinical Science, 1970,

38, 415. Sealey, J. E., Kirshman, J. D., and Laragh, J. H., fournal of Clinical
. Investigation, 1969, 48, 2210.

" de Wardener, H. E., British Medical fournal, 1969, 3, 676

- Edwards, C. R. W., Chard, T., Kitau, M. J., and Forsling, M. L., fournal of Endocrinology, 1970, 48, xi.
}

interfere with the action of such a natriuretic hormone, thus altering the normal cycle of electrolyte excretion. Alternatively, since vasopressin secretion patterns have been studied in neither urine nor blood by recently available specific radioimmunoassay techniques ${ }^{9}$ it is possible that a reduction in the usual nocturnal secretion of antidiuretic hormone is concerned in steroid-induced nocturia.

\section{Bath Clinical Meeting}

Bath was probably uniquely fitting as a setting for last week's B.M.A. Annual Clinical Meeting. Its long traditicn of treatment of rheumatic disorders linked it with the Heberden Society, while the Royal College of Physicians of London, the third participant in the meeting, shares with Bath an association with the age of elegance in medicine. This was the first occasion on which a royal college has joined with the B.M.A. in organizing a clinical meeting. Its symposium on coronary care, reported in full at p. 229 , was notable for the active participation of the audience. More such contacts between those responsible for medical education and clinicians at the grass-roots are to be encouraged, since only in this way can each know what the other is thinking.

The Heberden Society's programme on Saturday morning showed the value of the contribution specialist societies can make in education. It also demonstrated the rapid advances being made in the understanding and management of rheumatic disorders. These sessions, taken together with the exhibition of the local hospital activities, made it clear that Bath is in the forefront of the current explosion of applied research in regional centres. Sir Barnes Wallis's Bath Institute of Medical Engineering is prominently active in this field and has 42 projects in hand, half of which have been approved for further development.

That the meeting ran so smoothly was in large part due to the efforts of Dr. G. D. Kersley, the chairman of the local organizing committee, and his colleagues Dr. A. A. Graham, the honorary general secretary, and Dr. K. R. Gough, the honorary science secretary. The meeting was greatly indebted to Dr. D. W. Barritt, the local secretary for the Royal College of Physicians, and Dr. H. L. F. Currey, secretary for the Heberden Society's sessions, for the part they played in producing a balanced programme of interest to practising clinicians.

Ladies attending the meeting could choose between the attractions of sight-seeing in Bath and excursions to Longleat and Wellow arranged by the Ladies' Committee under Mrs. Rose Glaser and Mrs. Enid Gibson. On each of the three evenings of the meeting visitors were welcomed at receptions given by the Bath Division, the City of Bath, and the South Western Regional Board. Even the most obsessional attender at the scientific sessions was thus given a chance to see the Assembly Rooms, the Pump Room, and the Guildhall. History and beauty are inescapable in Bath; its elegance and its compactness as a conference centre readily account for the five visits by the B.M.A. since 1838 . 